THE BACTERIAL PURIFICATION OF SEWAGE. BY ALBERT GLYNDON.

It is only about twenty years since the first experiments in bacteriological sewage purification were made. Schloesing and Muntz in France, Warrington and Frankland in England, and the Massachusetts State Board of Health were the pioneers of the movem en t. Th e

necessity for sewage purification is distinctly a modern on e. It has grown out of the develop. ment of $\mathrm{the}$ water carriage system. In $\mathrm{s}$ s $\mathrm{s}$ e $\mathrm{m}$. In many and fearful wer e the diseases due to the bad sanitation of streets and $\mathrm{h}$ ou ses. Now, however, architects and engineers have solved that old problem, a $n$ by means of the water car

riage sewerage systems, they are able to have the poisonous wastes safely conveye away from human habitation. Nevertheless, the problem of the ultimate aisposal of sewage has not yet been thoroughly solved. Man has sought to deal with the subject by 'building sewers to the nearest stream, and thereby removing the nuisance as far as he is concerned. But in doing this he has only transferred it in a degree to some other community, and has established the modern evil f stream pollu of stream pollut dwell upon the results of this evil. It is sufficient to point out that it contaminates t owns, kills fish, makes rivers unpleas ant for boating a n bathing, $\mathrm{r}$ enders the water practically useless, a $n$ a id $s$ in the spreading of typhoid

It would be f o o lish to

make laws against the passing of sewage into streams if there were no better ways of disposing of it. Modern science, however, has come to the rescue. Filters have been invented and put into operation which have the power to convert the most foul and turbid sewage into clear, sparkling water, and which enable men to pass harmless effluents into the rivers.

The modern method of filtration is not a mechanical nor a chemical one; these systems have been tried, but have faile to dispose of the large quantities of impurities in solution. It is a system of breaking up animal and vegetable matter into their harmless constituent parts by means of the action of bacteria which inhabit the sewage. It is really a process of combustion or oxidation, that is to say, the converting of organic substances into inorganic. The same kind of action is seen frequently in nature. It takes place in
The liquid becomes finely divide in passing through the air, and reaches the ground in fine particles. Here the bits of grease, soap, and food refuse remain on the surface, where they are slowly oxidized by the aerobic bacteria. The liquid passes on through the earth, and is attacke by millions of micro-organisms, which search each drop for food. After a time the liquid becomes practically pure, and the retaine solids have disappeared, passing off as carbonic acid, wat e r, nitrogen, or $o x$ ides of nitrogen.

Many are the varieties of system s devised for the disposal of sewage. The patent offices of both England and the United $\mathrm{S}$ t a t e s have b e en flooded with new in ventions for sewage $t r$ e a t-

A Municipal Sewage Disposal Plant.

conversion of foliage into dried-up dead leaves and in all processes of decay. The bacterial sewage treatment system is simply the adaptation of this method of nature to the requirements of man.

Before one can understand how it is possible for such purification to be accomplished, two things must be realized. The first is the enormous force of bacteria present. The second is the insignificant bulk in sewage that requires purification. As many as $115,000,000$ bacteria have been counte in one gramme (1-28 ounce)

ment. M a n y

have proved utterly worthless, but there are several which have been operated with entire satisfaction.

I will not attempt in this article to go into details of each different metho of sewage disposal, but I will give a brief description of the most important systems now in use.

The oldest of all forms of bacterial sewage disposal is known as land treatment, broad irrigation, or sewage farming. It was understood for a long time that land had the power of purifying sewage without its being $\mathrm{kn}$ ow $\mathrm{n}$ exactly what took place. Accordingly, sewage was passed over land for the purpose of purification, purification and at the same time was u sed for the fertilization of crops. Th is sy ste m has been in operation in many parts of Engl a $\mathrm{n} d$, but it can hardly be looke upon as a practical A Domestic Sewage Disposal Plant.

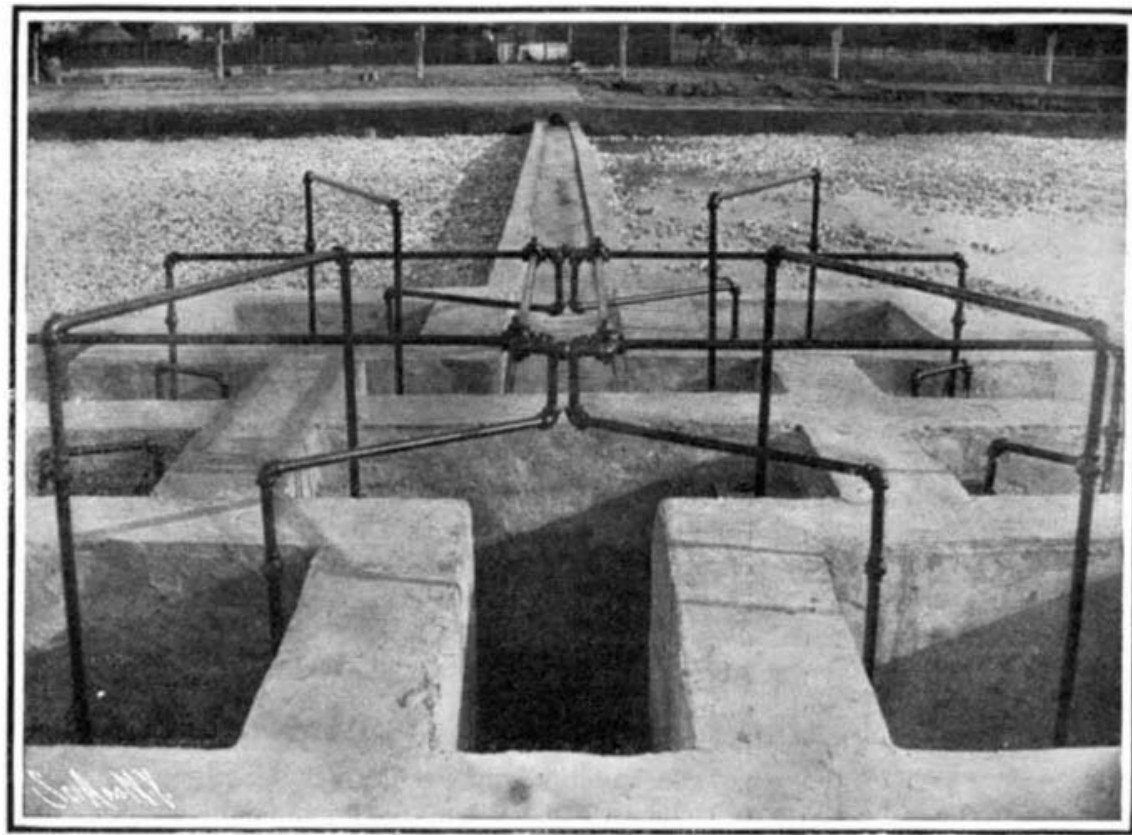

Automatic Airlock Apparatus for Controlling Contact Beds. of soil from a trench along which sewage had been running. They multiply with extraordinary rapidity and, were there no forces to interfere, one bacterium would have sixteen and a half million descendants in twenty-four hours. Ordinary sewage, on the other hand, only contains one part in a thousand of dead organic matter; 998 parts are pure water and one part harmless mineral matters.

The simplest example of bacterial sewage disposal is the throwing of a pan of dish water over the ground. some cases, however, most successful results have been The area of land require to purify a comparatively small volume of sewage is enormous, the expenses of operating are considerable, the land is liable to receive so much more liquid than the ordinary rainfall that it becomes "sewage sick," and useless either for purification or for raising crops. It is rapidly becoming an (Continued on page 458.) 
by hand levers which proved so successful on motor car No. 1 has been applied to car No. 2; but it is operate by air pressure controlle by a specially designe orerating valve. The car is starte at low speed and the engine disconnected or thrown into high spee
will, simply by means of the operating valves.

The initial trip of this car was made on September 14, when a run took place from Omaha to Valley, Neb., on the main line of the Union Pacific, a distance of 34.8 miles. On the west-bound trip no effort was made for a fast run, but special mention should be made of the performance of the car in ascending Elkhorn Hill, where the grade is 42 feet per mile. This hill was climbed at the rate of $32 \frac{1}{2}$ miles per hour. The return trip was made at an average speed of 37 miles per hour, with a maximum speed during the run of 52 miles per hour.

On September 22 the car made a second trial run to Valley and return, and on the west-bound trip an average speed of 39.4 miles per hour was maintained. On the east-bound trip the car made 25 miles from Valley to Gilmore in thirty minutes, or at an average spee of 50 miles per hour. Several miles were covere in 57 seconds-a rate of 63.2 miles per hour-and mile after mile was run at a speed of over a mile a minute.

\section{THE BACTERIAL PURIFICATION OF SEWAGE.} (C॰ntinued frøm page 456.)

out-of-date method except, perhaps, for finally disposing of sewage works effluents, or in isolate cases where tcpographical and other conditions are specially favorable to its adoption. Land treatment is use successfully at Berlin, Germany, on a tract of land of over 19,000 acres-larger than the city itself. It is kept in condition by convict labor. In one instance, a year of exceptional drought, the crops from these farms realized receipts which more than defraye all cost of administration and maintenance. Land treatment on the whole, however, is haphazard, uncertain, and ex pensive.

In 1895 Donald Cameron, of Exeter, England, brought the septic tank into prominence. This consists of a large tank, in which sewage is allowe to remain, where it is acte upon by anaerobic bacteria-micro-organisms that live without the presence of air. Sewage contains a considerable portion of solid matter in suspension. By means of anaerobic action part of it becomes liquefied and goes into solution, part rises to the top as scum, while part descends to the bottom as sludge. The inlet and outlet of the tank are place below the surface, so that the sewage may pass quietly through with as little commotion as possible. The scum which rises to the top becomes oxidized after a time, and passes off into the air as harmless gas. A certain amount of decomposition takes place in the sludge at lates very slowly at the bottom. At a septic tank at Mansfield, Ohio, only a few inches of deposit were Mansfield, Ohio, only a few inches of deposit were
drawn off after it nad been in use for a year and a half. drawn off after it nad been in use for a year and a half.
The septic tank has prove a most useful factor in sewage purification. It is use extensively as preliminary treatment for contact beds and percolating filters. It cannot, however, be considere by itself as a system of purification; it can be used successfully only as part of one.

There are some small towns in this country. however, where septic tanks alone have been used. The results in these places have invariably been very poor. The septic tank by itself is regarde by sanitarians as little better than an apology for a sewage disposal plant. In scme cases, however, when only a low degree of purification is needed, such as when sewage is put into the ocean, septic tanks have prove useful.

Perhaps the most practical method of sewage disPerhaps the most practical method of sewage dis-
posal is the combination of the septic tank and the conposal is the combination of the septic tank and the con-
tact bed. The contact be system was devise by W. J. tact bed. The contact be system was devise by W. J.
Dibdin, who installe the famous be at the town of Sutton, England. In this system sewage is first passed through a screen, to prevent the floating particles from blocking the interstices of the bed. It is then passed over a coarse-graine bacteria bed. This consists of a tank three feet deep fille with broken stone, coke, burnt ballast, or other suitable material not more than three inches in diameter. It is supplie with underdrains, so that it can be easily emptied. The sewage is allowe to enter the bed until the level of the filtering material is reached. The inlet is then closed, arid the sewage is allowe to remain standing "in contact" for a certain length of time. During this period the aerobic bacteria to their work. They oxidize the organic matter in solution, and in their search for food they decompose a considerable portion of the impurithey decompose a considerable portion of the impuri-
ties. Furthermore, certain ferments knowns as enzymes aid in the work of decomposition, while the solid particles adhere to the filtering material. The sewage is then allowed to flow slowly out of the bed, leaving many impurities upon the filter material. It flows into another similar bed, where further similar action takes place. Now that the be is empty, aerobic action goes on among the particles of sewage left in the interstices of the material. Before the next flush comes, most of the spongy matter in the be has been converte into gases. When the bed fills again, the gas is driven out the be into the air above.

Such is the method in use at Sutton. It is simple and effective, and has been widely used in systems laid out more recently. After the sewage has been treated
in a septic tank, it generally nee only be treated in ne contact be to secure the necessary purification.

Most septic tank-contact bed systems contain several bacteria beds, so that while one bed is filling, another may be in contact, another emptying, and another rest nig empty. Four is a favorite number of beds for a mall town plant, while six are often used.

The contact be system involves only a small fall, so that it can be applied to almost any district. It has country and in England. The secret of its success is the regularity of the time of contact and aeration. the regularity of the time of contact and aeration.
Experience has shown that unless such regularity is maintaine the bacteria will not remain in healthy conition.

At Manchester, England, is the largest septic tankcontact bed system in the world. The beds are opened an closed at regular intervals by hand. In the more invention of automatic airlock apparatus has made it possible to have the beds fill and empty at regular intervals automatically.

A more recently devised system of filtration, and one that is gaining favor in England, is known as intermittent downward filtration, percolating, or trickling filis distribute in intermittent loses-often by means of a large revolving sprinkler. They are fille with material similar to that use in contact beds. At the bottom there is an open space for the circulation of air.

In order that percolating filters work successfully, great care must be taken in their construction. It is essential that air should always be present in all parts of the filter, scum must not be allowed to accumulate; the filtrate may come from the filter easily and force air to come in by induction. During the fall of the sewage through the bed, the aerobic bacteria get a splendid opportunity to oxidize organic matter, provide they have a sufficient supply of air. The effectiveness of a percolating filter increases with its depth, so that the filters are made as deep as possible. They are generally use with septic tanks. This system is in use at Birmingham and Hanley, England, but it has practically never been applie in this country. The objections to its use are first the great fall require and secondly the danger of stoppage through frost un less artificial heat is used. At an experimental plant at Leeds a purification of over 80 per cent was secure in three minutes by this method.

The metho of intermittent downwar filtration is largely use in New England. It is, however, merely an adaptation of the old system of land treatment. It consists of passing sewage over soil intermittently, so that the land after receiving one charge of sewage is allowed to rest for a certain space of time before receiving the next. Underneath are generally place under-
drains so that the effluent can easily escape. Although areas averaging as much as from ten to twenty acres per million gallons are necessary for these beds, the results obtaine have been satisfactory. It is frequently necessary to pump the sewage to the filters. The best-known examples of intermittent downwar filtration through sand are those at Brockton and Framingham, Mass. In both cases pumping stations are required. This system has one or two drawbacks besides its expense. Unless great care is taken, the percolating through the material, while the beds frequently freeze and become useless in winter.

There is no douot that the bacterial process of sewage treatment has come to stay. The question raise is no longer shall the bacterial system be used, but which kind of bacterial system best complies with the given ccnditions. All the methods I have described work successfully under the proper conditions, but the contact bed system has proved the most generally applicable because of the small fall require and its ability to operate in all weather.

\section{THE FLAX INDUSTRY OF TO-DAY.}

Of all the plants cultivate for fiber, flax, Linum know of its existence from the times of the first authentic records. Even cotton, which 'was mentioned in the writings of Herodotus in $445 \mathrm{~B}$. C., must take its place as a comparatively modern product with reference to its forerunner-linen. Because of this very antiquity, the origin of the flax plant is rather uncertain; but it is believed that it arose in the region it was cultivate and manufacture by the Swiss lake wellers in the Stone Age in Europe is prove by the well-preserved specimens of straw, fiber, yarn, and cloth to be found in the museums. This ancient flax was, however, from another species, Linum angustifølium. The Egyptians produce and used flax thou- sands of years ago, and the Chaldæans and Babylonians arried its use to the highest state of development, mploying it particularly in tapestry work. Three housand years ago the Phœnicians extende the culture, the Greeks and Romans made it a household fiber. It is claime that the ancient Mexicans were acquainte with both flax and hemp, and their culture in that country goes back far beyond the earliest date of our civilization. It was introduce in this country in Massachusetts as early as 1630 .

While the plant can be grown in nearly every portion of the temperate world, flax is cultivated, primarily, for the production of fiber in central and northern Italy. In southern Russia, British India, Argentina, and the Unite States it is grown almost exclusively for see production; in these regions the straw is used for fuel, stable bedding, and sometimes for forage. In a few localities in this country the straw is use for paper stock, or is made into up holstering tow. While the cultivation of flax for seed, and the manufacture of this into oil and oil-cake, have grown into industries of enormous proportions in the Unite States, only in a few vicinities is the plant grown for the production of spinning fiber. At Yale in Eastern Michigan, at Northfield and Heron Lake, Minn., and at Salem and Scio, Ore., the flax is cultivate for its fiber.

While flax was extensively grown and its fiber spun and woven during colonial times, it was use almost home product for consumption in the familes of the weavers, and it is probable that very little linen was manufacture for purposes other than
this. While it is possible that after the successful termination of the Revolutionary war the industry would have grown to considerable importance in the hands of the American people, with the abolition of factures, the invention of the cotton gin by Eli Whit ney checke its future development at once. This ney checke its future development at once. This
invention place within reach of the manufacturer a fiber that was cheaper than flax, that required less care in preparation, more easily worked, superior for many purposes, and decidedly inferior for very few, and in abandoned. Until within comparatively recent times the attempts to reintroduce it have been few and far between and generally unsuccessful. Additional reasons for this are found in the expenditure of time and labor entaile by the retting process, in the difficulty in spinning and weaving a fiber with as little elasticity as this, in the consequent precariousness of the mar gin of profit, and finally, in the fact that the demand general as is that for other textiles. Nevertheless, while the linen industry in the Unite States is not extensive to-day, a considerable advance, measure in percentages, has been made in the last ten years There are certain fields, such as the manufacture of linen carpet yarns, linen thread for the shoemaking industry, towels and towelings, in which the American manufacturers should be able to compete successfully. They have already occupied some and entere into others of these fields, and the growth of the industry in other directions is generally prophesied.

Nearly all the flax fiber used in the United States is importe from Russia, Holland, Belgium, and Ireland, while a small quantity comes from Italy and Canada. A great deal of the so-called "Irish flax" is grown in Belgium and sent to Ireland for preparation. (Russian) or fro $n$ Belgium Riga seed.

The culture of flax requires a deep, well-tilled soil in a high state of fertility. Wet soil such as some clays is disastrous to the crop. Similarly fatal are soils filled with the seeds of weeds. Moist, deep, strong loams upon upland in a fairly moist climate are especially favorable to the plant. The land must be deeply plowe and thoroughly harrowed. Because of a disease, flax-wilt, it cannot be cultivate year after year upon the same ground; but as the other ordinary crops are immune from the spores which remain in the soil, flax may be introduce in a rotation once in six or eight years.

Flax is sown early in the spring, broadcast like oats or wheat, the seeds being spread evenly at a depth of the growth of the plant is rapid, maturity being reached in about one hundre days. The crop must be thoroughly weeded, the operation beginning when it is about two inches above ground, as the quality of the plant when choked by weed is poor. The best flax is pulle out by the roots. This is one to avoid stain and injury, which would result from soil moisture while the cut stems were in the shock, to secure straws of the greatest possible length, to insure better curing of the straw and ripening of the seed, and to avoid the blunt cut ends of the fiber. The straw is often allowed to dry on the ground, and then to cure for two or three weeks in the shocks, though the practice varies somewhat in different countries. The seeds 